\section{ekf}

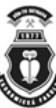

WTSOKÁ ŠKOLA BÁŇSKÁ

W EKONOMICKÁ FAKULTA

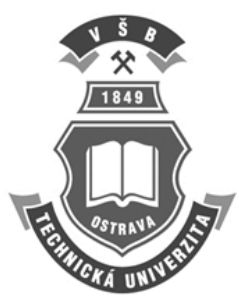

\title{
Modelovanie kauzálních väzieb medzi priamymi zahraničnými investíciami, exportom a ekonomickým rastom v Chorvátsku
}

\author{
Zuzana GALLOVÁ, Daniel STAVÁREK, Silesian University in Opava
}

\begin{abstract}
Foreign direct investment is generally considered to be an instrument how to stimulate economic growth of any country. For this purpose governments of transition countries try to encourage the inflow of foreign direct investment by various measures. The aim of this paper is to analyse the relation between foreign direct investment, economic growth and export in Croatia. For this purpose we apply cointegration analysis along with the vector error correction model. The results confirm the existence of a long-term relation between the variables analysed. We reveal a positive impact of GDP and negative impact of foreign direct investment on export.
\end{abstract}

\section{Keywords}

Cointegration, economic growth, error correction model, export, foreign direct investment.

JEL Classification: F41, F43

\footnotetext{
${ }^{\text {i }}$ Department of Finance, The School of Business Administration in Karvina, Silesian University in Opava, Univerzitní náměstí 1934/3, 73340 Karviná, Czech Republic. gallova@opf.slu.cz (corresponding author)

Research behind this paper was supported by Internal grant system of Silesian University within the project SGS $25 / 2010$ Financial Integration in the EU and Its Impacts on Corporate Sector.
}

\section{1. Úvod}

$\mathrm{V}$ rámci Európy je $\mathrm{z}$ ekonomického hl'adiska zaujímavým regiónom Západný Balkán. Po rozpade Juhoslávie a páde povojnových režimov na území novovzniknutých krajín bol spustený jednotlivými vládami uzdravovací proces ako na politickej, tak aj na ekonomickej scéne. $\mathrm{K}$ najlepšie sa ekonomicky rozvíjajúcim štátom spomedzi štátov Západného Balkánu (vynímajúc Slovinsko) sa radí Chorvátsko. Politické zmeny a vytvorenie novej vlády v roku 2000 výrazne dopomohlo $\mathrm{k}$ jeho napredovaniu. Chorvátska ekonomika je v posledných rokoch $\mathrm{v}$ solídnej kondícii. Krajina snažiaca sa o naštartovanie a udržanie ekonomického rastu uskutočňuje mnohé opatrenia. Vel'a zmien bolo vykonaných najmä na politickej úrovni ako aj $\mathrm{v}$ oblasti verejných financií, bankovníctva či v infraštruktúre. No napriek tomu má
Chorvátsko stále určité nedostatky, a to najmä v klúčových oblastiach, ako je podnikatel'ské prostredie, trh práce a stále vysoká nezamestnanost', nedokončená transformácia $\mathrm{z}$ centrálne plánovanej ekonomiky na tržnú, a to $\mathrm{v}$ oblasti privatizácie a reštrukturalizácie podnikov $-\mathrm{v}$ Chorvátsku zastáva vláda ešte stále dost' výrazne postavenie $\mathrm{v}$ oblasti ekonomiky, ako to je $\mathrm{v}$ porovnaní $\mathrm{s}$ inými transformujúcimi sa krajinami strednej a východnej Európy.

V snahe dosahovat' ekonomický rast a trvale ho udržovat' rastie $\mathrm{v}$ krajine dopyt po priamych zahraničných investíciách (PZI). Práve PZI sú často pripisované pozitívne účinky na ekonomický rast krajiny, pokles nezamestnanosti a pod. PZI okrem iného so sebou prinášajú do krajiny nové technológie, výrobné procesy, know how. Napriek týmto všetkým pozitívam býva téma PZI a ich dopad na ekonomiku 
krajiny diskutovaný či už na národnej, alebo nadnánadnárodnej úrovni. Existuje viacero teórii a prístupov $\mathrm{k}$ tejto problematike, ktoré na jednej strane podporujú, na druhej strane vyvracajú tvrdenie o pozitívnych účinkoch PZI na ekonomiku.

Často diskutovanou témou je kauzálny vzt’ah medzi ekonomickým rastom a exportom. Nielen ekonomické teórie, ale aj empirické výskumy sa snažia o dokázanie tohto vzt’ahu. Ako príklad je možné uviest' štúdie Dritsaki a kol. (2004), PachecoLopéz (2004) alebo Feridun a Sissoko (2006).

Ciel'om príspevku je skúmat' dlhodobé kauzálne väzby medzi spomínanými ekonomickými veličinami, ako je export, priame zahraničné investície a hrubý domáci produkt za časové obdobie takmer 10 rokov. Príspevok je rozdelený do šiestich častí. Prvá je venovaná prehl'adu empirických štúdií, ktoré sa zaoberajú problematikou PZI. V druhej časti sú stručne popísané tri základné veličiny, a to tempo rastu HDP, PZI a export v Chorvátsku za časové obdobie 10 rokov. Do tretej až šiestej časti sú rozdelené jednotlivé fázy výskumu.

\section{Prehl'ad literatúry}

Empirických štúdií, ktoré sa zaoberajú kauzálnymi väzbami medzi priamymi zahraničnými investíciami, exportom a ekonomickým rastom existuje dostatočné množstvo. Pre vytvorenie si prehl'adu v tejto oblasti sú nižšie uvedené výsledky výskumov, ktoré sa orientujú predovšetkým na transformujúce sa krajiny.

Orr (1991) sa vo svojej štúdii prikláňa k názoru, že PZI majú pozitívny vplyv na obchodnú bilanciu hostitel'skej krajiny, a to len za určitých podmienok. Priame zahraničné investície musia odoberat' od domácich dodávatel'ov a vyrábat' taký tovar, ktorý nahradí dovážané tovary a ktorý je zároveň z krajiny vyvážaný, inak na saldo obchodnej bilancie nepôsobia pozitívne. Borensztein a kol. (1998) testujú pomocou regresnej analýzy efekt PZI na ekonomický rast v rámci vybraných 69 rozvojových krajín, za časové obdobie 20 rokov. Demonštrujú pozitívny dopad PZI na dlhodobý rast prostredníctvom prísunu nových technológií do hostitel'skej krajiny. Tvrdia, že zahraničné investície prispievajú $\mathrm{k}$ ekonomickému rastu do väčšej miery ako domáce investície. Ďalej dokazujú, že vplyv PZI na ekonomický rast je silnejší, čím vyššia je úroveň l'udského kapitálu v hostitel'skej krajine. Fabry (2001) pomocou bivariatného Grengerovho testu kauzality skúma vzt'ah medzi PZI, exportom a priamymi zahraničnými investíciami na skupine 10 krajín $\mathrm{z}$ regiónu strednej a východnej Európy. Na základe tohto testu sa preukázal vzt’ah $\mathrm{v}$ smere od PZI $\mathrm{k}$ ekonomickému rastu $\mathrm{v}$ prípade Albánska a Ruska, zatial' čo opačný vzt'ah, t.j. od ekonomického rastu $\mathrm{k}$ PZI, bol nájdený $\mathrm{v}$ prípade Mad'arska, Pol'ska a Rumunska. Autorka v závere na základe prevedeného výskumu konštatuje, že export má silnejší vplyv na ekonomický rast než PZI. Tiež sa v jej výskume na základe Grangerovho testu kauzality ukázalo, že vzt'ah $\mathrm{v}$ smere od PZI k exportu vo vybraných krajinách nebol preukázaný. Použitím Grangerovho testu kauzality, Chakraborty a Basu (2002) sa pokúšali nájst' väzbu medzi PZI a ekonomickým rastom v Indii. Výskum preukázal, že ekonomický rast nie je závislý na PZI, ale naopak ekonomický rast a liberálna obchodná politika krajiny prispievajú k prílivu PZI do krajiny. Štúdia PachecoLopéz (2004) testovaním preukázala obojsmernú príčinnú súvislost' medzi exportom a priamymi zahraničnými investíciami v Mexiku: vývoz stimuluje PZI a PZI naopak podporujú vývoz. Dritsaki a kol. (2004) pomocou vektorového autoregresného modelu (VAR) skúmali kauzálne väzby medzi PZI, ekonomickým rastom a exportom v Grécku. Výskumom preukázali obojstranný vzt’ah medzi exportom a ekonomickým rastom a jednosmerný vzt'ah medzi PZI a ekonomickým rastom v smere od PZI k hrubému domácemu produktu a jednosmerný vzt'ah medzi PZI a exportom v smere od PZI k exportu. Neuhas (2005) sa tiež zaoberal problematikou kauzálnych väzieb medzi PZI a hospodárskym rastom. Pozitívny vplyv PZI na hospodársky rast sa mu podarilo preukázat' na vzorke 10 transformujúcich sa krajín strednej a východnej Európy za časové obdobie 1994 - 2002. Zamrazilová (2006) dochádza vo svojej štúdii $\mathrm{k}$ záverom, že v Českej republike zahraniční investori priniesli do ekonomiky nielen finančné prostriedky, ale ich vstup zlepšil podnikom pod zahraničnou kontrolou prístup na svetové trhy a zvýšil ich adaptáciu na meniace sa podmienky dopytu na vyspelých trhoch. Silná exportná orientácia a výkonnost' podnikov pod zahraničnou kontrolou prispela $\mathrm{k}$ postupnému zvyšovaniu exportnej výkonnosti.

\section{Prehl'ad vývoja jednotlivých údajov modelu $v$ rokoch $1999-2008$}

Hospodársky rast $\mathrm{v}$ rokoch $2002-2007$ býva v Chorvátsku označovaný ako stabilný a v priemere za tieto roky sa pohyboval okolo $4,8 \%$ ročne, tento jav sa pripisuje investíciám realizovaným na území krajiny. Za uvedených 10 rokov $(1999$ - 2008) sa priemerné tempo hospodárskeho rastu pohybovalo na úrovni 3,67 \% ročne, podobne ako v Mad'arsku či Českej republike. V roku 2008 bol zaznamenaný pokles na $2,4 \%$. Tento pokles bol v súvislosti s prejavovaním sa finančnej krízy. Finančná kríza sa odrazila na makroekonomických ukazovatel'och Chorvátska, ked’že ide o malú otvorenú ekonomiku 
závislú od exportu a vývoja ekonomickej situácie v zahraničí. Vývoj tempa rastu v rokoch 1999 - 2008 zachytáva graf 1 .

\section{Graf 1 Tempo rastu HDP v \%}

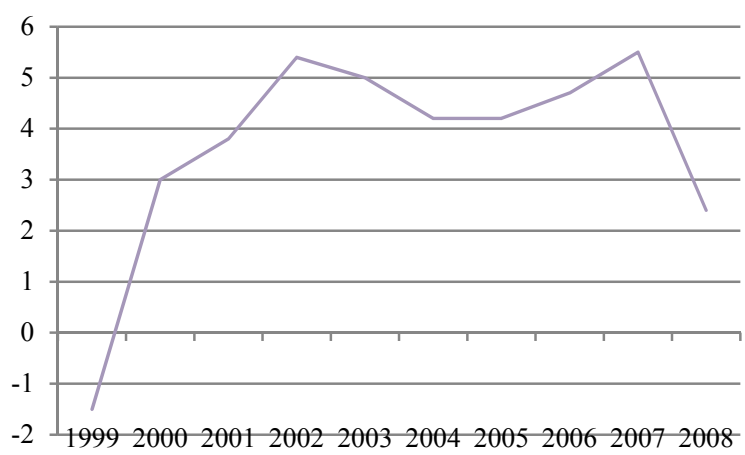

Zdroj: vlastné spracovanie podl'a údajov Chorvátskej národnej banky

Priame zahraničné investície $\mathrm{v}$ Chorvátsku mali spočiatku $v$ značnej miere charakter vel'kých privatizačných obchodov. Jedna $\mathrm{z}$ najväčších PZI sa uskutočnila v roku 1999, ked' Deutsche Telekom získal $35 \%$ podiel v spoločnosti Hrvatski Telecom v hodnote 850 mil. USD, o dva roky neskôr, v roku 2001, získal d’alších $16 \%$. Od roku 2000 bola väčšina PZI sústredená do bankového sektoru. Ako príklad môžeme použit' Privrednu Banku Zagreb, ktorej tretinu odkúpila talianska banka, Banka Commerciale. D̆alej 60\% podiel v Rijeckej Banke získala Bayerische Landsebank a $63 \%$ podiel v Splitskej Banke získala talianska Unicredito. Za zmienku tiež stoja d'alšie tri PZI. Ide o firmy Calzedonia, INA Industrija a Valoviti Papir Dunapack. V prípade firiem Calzedonia a Valoviti Papier Dunapack šlo o PZI na zelenej lúke, firma INA Industrija bola sprivatizovaná.

Z grafu 2, ktorý zachytáva stavy priamych zahraničných investícií v Chorvátsku za obdobie 10 rokov, jednoznačne vidno, že do roku 2007 sa stavy PZI navyšovali a pokles nastal podobne jako $\mathrm{v}$ prípade tempa rastu HDP v roku 2008.

Graf 2 PZI - stavy za sledované obdobie v mil. EUR

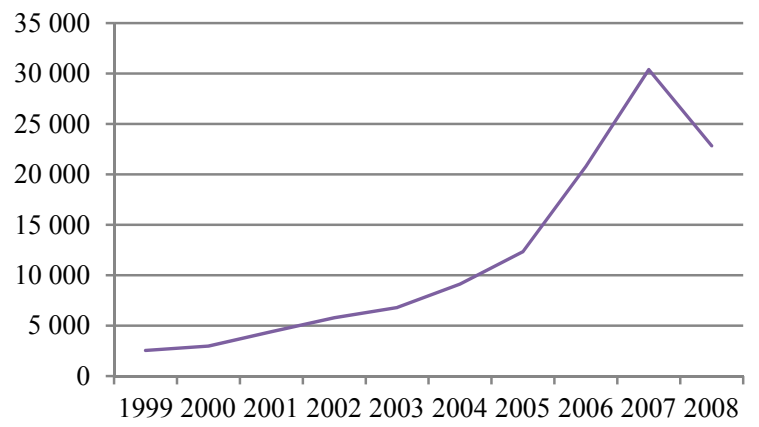

Zdroj: vlastné spracovanie podl'a údajov z Chorvátskej národnej banky a UNCTAD
Ako aj vyplýva zo štúdie Moore a Vamvakidis (2007), Chorvátsko zaostáva v oblasti získavania zahraničných investícií na zelenej lúke. To, že väčšina PZI sa uskutočnila najmä vo forme privatizácie, môže byt' označené za mierny nedostatok Chorvátska $\mathrm{v}$ tejto oblasti. Ak sa tvrdí, že PZI majú pozitívne prispievat' $\mathrm{k}$ rozvoju regiónu a $\mathrm{v}$ globále celého štátu ide najmä o PZI, ktoré sú uskutočnené na zelenej lúke. Teda investície predstavujúce výstavbu nového podniku.

Chorvátsko je krajinou, ktorá je výrazne závislá na zahraničnom obchode. Jej traja najvýznamnejší exportní partneri sú Taliansko, Bosna a Hercegovina a Nemecko. Od roku 2000 je členom Svetovej obchodnej organizácie, zaoberajúcej sa pravidlami obchodu medzi jednotlivými krajinami, a to na globálnej úrovni. Tomuto členstvu teda podriad'uje aj svoju obchodnú politiku štátu. Často je Chorvátsku vytýkané, že nevyužíva svoj potenciál, čo sa týka zahraničného obchodu a exportu, a čísla vyjadrujúce tento stav by mohli byt' ovel'a priaznivejšie. $Z$ grafu 3 je jasný rastúci trend exportu, napriek tomu stav obchodnej bilancie krajiny nie je príliš optimistický. Tempo rastu importu je rýchlejšie v porovnaní s tempom rastu exportu a krajina vykazuje rastúci trend deficitu obchodnej bilancie. Za rastom exportu stojí vo výraznej miere cestovný ruch a s tým spojené služby. V rokoch $2004-2008$ predstavoval deficit obchodnej bilancie k HDP v priemere $22,5 \%$ ročne. $\mathrm{V}$ roku 2009 tento ukazovatel' zaznamenal pokles, a to na $16,97 \%$, a to vzhl'adom na krízu, vd'aka ktorej sa znížil objem importu výraznejšie než objem exportu. Chorvátska vláda sa neustále snaží o zvýšenie exportnej sily chorvátskych výrobkov. Práve $\mathrm{v}$ tejto oblasti by sa mohla prejavit' sila priamych zahraničných investícií a podporit' export krajiny. Chorvátsko je však charakteristické $\mathrm{v}$ porovnaní $\mathrm{s}$ ekonomicky príbuznými krajinami nízkym objemom priamych zahraničných investícií, a to najmä investícii na zelenej lúke.

Graf 3 Vývoj exportu za sledované obdobie v mil. EUR

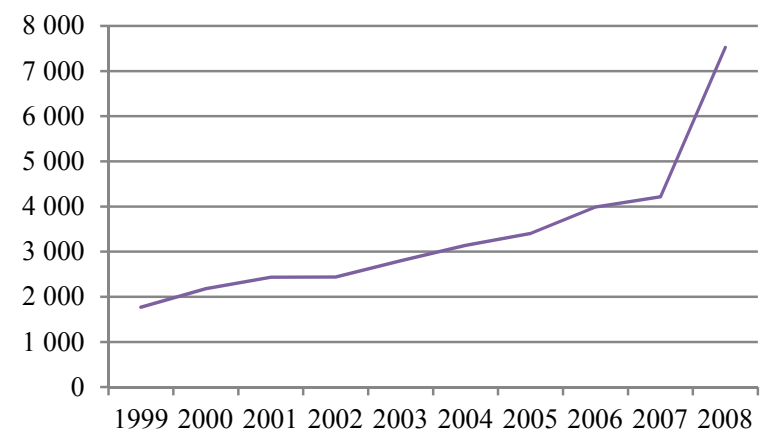

Zdroj: vlastné spracovanie podl'a údajov z Eurostatu 


\section{4. Údaje a špecifikácia modelu}

Pre skúmanie kauzálnej závislosti medzi hrubým domácim produktom (HDP), exportom (EXP) a priamymi zahraničnými investíciami (PZI) budú využité štvrt'ročné údaje za časové obdobie od prvého štvrt'roku 1999 po tretí štvrt'rok 2008. Do výskumu nie je zahrnutý posledný štvrt'rok roku 2008 vzhl'adom na to, že $\mathrm{v}$ čase jeho realizácie neboli dostupné údaje za toto obdobie. HDP je vyjadrené $\mathrm{v}$ tržných cenách, PZI zachytáva stavy priamych zahraničných investícii a Export vývoz tovarov a služieb $\mathrm{v}$ bežných cenách. Údaje HDP a EXP sú získane z Eurostatu a PZI z Národnej banky Chorvátska. Všetky údaje sú vyjadrené v miliónoch EUR. Údaje exportu a hrubého domáceho produktu sú sezónne očistené, a to z toho dôvodu, že Chorvátsko je krajinou, ktorá t’aží predovšetkým $\mathrm{z}$ cestovného ruchu $\mathrm{v}$ letných mesiacoch, čo sa prejavilo aj $\mathrm{v}$ hodnotách exportu a HDP. Po sezónnom očistení boli jednotlivé veličiny zlogaritmované. Logaritmovanie bolo uskutočnené, aby sme dosiahli zmenšenie rozptylu jednotlivých časových rád a zabezpečili následne ich stacionaritu. Zlogaritmované časové rady sú označené vel'kým písmenom L pred názvom každej rady. Pre uskutočnenie kointegrácie, pomocou ktorej testujeme dlhodobé kauzálne väzby medzi premennými, je potrebné, aby zlogaritmované časové rady boli stacionárne až na prvých diferenciách I(1) a na svojich hodnotách nestacionárne. Kauzálny vzt’ah medzi uvedenými veličinami bude skúmaný na základe vektorového autoregresného modelu (VAR) v nasledujúcej podobe:

$$
E X P=f(H D P, F D I) \text {. }
$$

\section{Unit root test (test jednotkového koreňa)}

Klúčovým bodom analýzy je rozhodnutie o existencii jednotkového koreňa prostredníctvom Augmented Dickey - Fuller testu (ADF test). Tento test je využívaný so zámerom preukázat, že jednotlivé premenné sú integrované na I (1) - teda stacionárne na prvých diferenciách. Pre tento dôkaz je sformulovaná nasledujúca rovnica:

$$
\Delta X_{t}=\delta_{0}+\delta_{1} t+\delta_{2} X_{t-1}+\sum_{i=1}^{k} \alpha_{i} \Delta X_{t-i}+u_{t} .
$$

ADF test slúži k určeniu jednotkového koreňa $X_{t}$, a to na úrovni všetkých logaritmovaných veličín v čase $t$. Premenná $\Delta X_{t-i}$ vyjadruje prvú diferenciu s oneskorením a $u_{t}$ odhaduje chybu autokorelácie. Koeficienty $\delta_{0}, \delta_{1}, \delta_{2}$ a $\alpha_{i}$ sú odhadované. Nulová a alternatívna hypotéza pre existenciu jednotkového koreňa v premennej $X_{t}$ je (Dickey a Fuller, 1979):

$$
\begin{aligned}
& H_{0}: \delta_{2}=0, \\
& H_{\varepsilon}: \delta_{2}<0 .
\end{aligned}
$$

Výsledok ADF testu, ktorý potvrdzuje stacionaritu všetkých troch časových radov na prvej diferencii, je uvedený $\mathrm{v}$ tabul'ke 1 . V prvej časti tabul'ky sa nachádzajú údaje zachytávajúce hodnoty, ktoré vyjadrujú nestacionaritu skúmaných časových radov na ich hodnotách, a $\mathrm{v}$ druhej polovici tabul'ky sú zaznamenané údaje vyjadrujúce stacionaritu časových radov na prvej diferencii. Všetky časové rady boli či stacionárne, alebo nestacionárne už na $1 \%$ hladine významnosti.

\section{Kointegrácia - Johansenov kointegračný test}

Tým, že časové rady sú stacionárne na prvých diferenciách, je splnený predpoklad pre uskutočnenie kointegrácie. Kointegrácia (cointegration) môže byt' interpretovaná ako vzt’ah určitej dlhodobej rovnováhy medzi ekonomickými veličinami. Jednotlivé časové rady sú síce nestacionárne, ale ich spoločný kointegračný pohyb $\mathrm{v}$ čase dlhodobo smeruje napr. $\mathrm{v}$ dôsledku rôznych tržných síl $\mathrm{k}$ určitému rovnovážnemu stavu, aj ked' je možné, že v krátkodobých časových úsekoch dochádza $\mathrm{k}$ vychýleniu od takéhoto dlhodobého vybalancovania (Cipra, 2008).

Pri testovaní kointegrácie ide o stanovenie počtu $r$ kointegračných vztahov $\mathrm{v}$ danom VAR modeli. Kointegrácia sa potvrdzuje, ak platí, že $r>0$. Pre testovanie kointegrácie sa dnes $\mathrm{v}$ praxi najčastejšie používa Johansenov kointegračný test, ktorý bol využitý aj v rámci tohto skúmania.

$\mathrm{Za}$ účelom uskutočnenia Johansového kointegračného testu je potrebné získat' údaj optimálneho časového oneskorenia, čo je $\mathrm{v}$ našom prípade 2 obdobia. Tento optimálny počet oneskorení bol zvolený

Tabul'ka 1 DF/ADF Unit Root Tests (testy jednotkového koreňa)

\begin{tabular}{|l|c|c|c|c|}
\hline & \multicolumn{2}{|c|}{ Na hodnotách } & \multicolumn{2}{c|}{ Na prvej diferencii } \\
\hline Premenná & Oneskorenie & Test statistic ADF & Oneskorenie & Test statistic ADF \\
\hline LEXP_sa & 0 & $-3,1351^{*}$ & 1 & $-7,4565^{*}$ \\
\hline LPZI_stavy & 2 & $-2,4850^{*}$ & 0 & $-5,2889^{*}$ \\
\hline
\end{tabular}




\begin{tabular}{|c|c|c|c|c|}
\hline LHDP_sa & 0 & $-2,3956^{*}$ & 0 & $-6,7517^{*}$ \\
\hline
\end{tabular}

Poznámka: *,** značí významnost' na $1 \%$ a $5 \%$ v tomto poradí

základe Akaike informačného kritéria aplikovaného na odhad nediferencovaného modelu VAR. Následne môže byt' skúmaná kointegračná väzba medzi uvedenými veličinami (Johansen, 1988, Johansen a Juselius, 1990). Výsledky kointegračného testu poskytuje tabul'ka 2. Na základe nej môžeme tvrdit', že existencia dlhodobého vzt’ahu bola medzi danými veličinami preukázaná a bola nájdená kointegračná väzba. Kointegračná rovnica má nasledujúci tvar:

$L E X P=2,7963 L H D P-0,4655 L P Z I-13,0317$, (3)

$$
(0,31155)(0,09293)(1,98824) \text {. }
$$

$\mathrm{Z}$ uvedenej rovnice vyplýva, že pri raste HDP o $1 \%$ dochádza $\mathrm{k}$ rastu exportu o $2,79 \%$ a pri raste PZI o $1 \%$ klesá objem exportu o $0,46 \%$. Tieto výsledky ukazujú, že HDP a export sa vyvíjajú rovnakým smerom, čo je $\mathrm{v}$ súlade $\mathrm{s}$ ekonomickou logikou. Rýchlejšie tempo rastu exportu než celkového HDP navyše ukazuje na neproporcionálne nižší príspevok exportu $\mathrm{k}$ hospodárskemu rastu. Pokles objemu exportu pri prílive PZI je síce $\mathrm{v}$ rozpore $\mathrm{s}$ teoretickými prínosmi zahraničných investícií, avšak potvrdzuje vyššie zmienenú prevahu privatizačných PZI a nedostatočnú schopnost' Chorvátska prilákat' nové investície, ktoré by zvýšili exportnú výkonnost' ekonomiky Chorvátska a následne podporili aj jeho hospodársky rast.

\section{Error corection model - model korekcie chyby}

$\mathrm{V}$ rámci kointegrácie sme zistili, že medzi danými veličinami exituje dlhodobá väzba, no kointegrácia odhliada od možnosti vzniku krátkodobých výkyvov medzi skúmanými veličinami. Na odhalenie týchto výkyvov slúži v rámci kointegrácie Model korekcie chyby (Error corection model - ECM), ktorý je adekvátnym nástrojom ku skúmaniu krátkodobých odchyliek nutných k dosiahnutiu dlhodobej rovnováhy medzi skúmanými premennými (Cipra, 2008). Model korekcie chyby má nasledujúcu formu:

$$
\begin{aligned}
\Delta L E X P G_{t}= & \text { lagged }\left(\triangle L E X P, \Delta L H D P_{t}, \Delta L P Z I_{t}\right) \\
& +\lambda u_{t-1}+V_{t},
\end{aligned}
$$

kde lagged predstavuje určitý počet oneskorení vysvetlujúcich premenných. Optimálny počet oneskorení je určený na základe Akaike kritéria. $\Delta$ znamená prvú diferenciu veličiny, $u_{t-1}$ sú odhadované reziduálne zložky $\mathrm{z}$ dlhodobého vzt'ahu, zisteného z kointegračného testu, $1<\lambda<0$ prestavuje rýchlost' návratu k dlhodobej rovnováhe a $V_{t}$ je náhodná zložka bieleho šumu.

Pre modelovanie korekcie chyby bol zistený optimálny počet oneskorení, a to dve obdobia. Vhodné nastavenie modelu bolo následne testované pomocou niekol'kých testov reziduálnych zložiek. Konkrétne sa jednalo o test autokorelácie (LM - test, ktorý je založený na Lagrangerových multiplikátoroch), test normality a test heteroskedasticity. Testovanie vylúčilo existenciu všetkých troch javov a potvrdilo sa, že model je vhodne zvolený.

Výsledok modelu korekcie chyby je zachytený $\mathrm{v}$ tabul'ke 3. Model korekcie chyby $\mathrm{v}$ skúmanom vzt'ahu medzi veličinami EXP, PZI a HDP vysvetl'uje približne 5\% mieru konvergencie $\mathrm{k}$ rovnovážnemu dlhodobému vzt'ahu v prípade vzniku krátkodobých šokov.

Tabul'ka 2 Johansen kointegračný test premenných LEXP_sa, LPZI_stavy a LHDP_sa

\begin{tabular}{|c|c|c|}
\hline Nulové hypotézy & Trace Statistic & Kritická hodnota 0,05 \\
\hline$r=0$ & 66,6466 & 35,1927 \\
\hline$r<=1$ & 22,3119 & 20,2618 \\
\hline$r<=2$ & 7,6799 & 9,1645 \\
\hline Nulové hypotézy & Max-Eigen Statistic & Kritická hodnota 0,05 \\
\hline$r=0$ & 44,3347 & 22,2996 \\
\hline$r<=1$ & 14,632 & 15,8921 \\
\hline$r<=2$ & 7,6799 & 9,1645 \\
\hline
\end{tabular}

Tabul'ka 3 Model korekcie chyby

\begin{tabular}{|c|c|c|c|c|c|}
\hline & $\Delta L E X P_{t-1}$ & $\Delta L H D P_{t-1}$ & $\Delta F D I_{t-1}$ & $\Delta L E X P_{t-2}$ & $\Delta L H D P_{t-2}$ \\
\hline$\Delta L E X P_{t}$ & $-0,527329$ & 1,027523 & $-0,041744$ & $-0,609062$ & $-0,271467$ \\
\hline & $(0,14016)$ & $(0,29497)$ & $(0,07004)$ & $(0,15354)$ & $(0,26528)$ \\
\hline & $\Delta L F D I_{t-2}$ & $u_{t-1}$ & $V_{t}$ & & \\
\hline$\Delta L E X P_{t}$ & $-0,097378$ & 0,047610 & 0,034214 & & \\
\hline
\end{tabular}


$(0,07162)$

$(0,01694)$

$(0,01307)$

Poznámka: v zátvorkách sú uvedené hodnoty smerodatných odchyliek

\section{Záver}

Príspevok sa zaoberá skúmaním kauzálneho vzt’ahu medzi exportom, hrubým domácim produktom a priamymi zahraničnými investíciami Chorvátska. Pre výskum boli použité kvartálne údaje, a to za obdobie takmer desiatich rokov. Konkrétne od 1.Q. 1999 do 3. Q. 2008. Spomínane údaje boli na začiatku testovania najskôr upravené. Hrubý domáci produkt a export boli sezónne očistené, a to z toho dôvodu, že chorvátska ekonomika je výrazne ovplyvňovaná cestovným ruchom predovšetkým v letných mesiacoch. Upravené údaje boli použité k prvému testovaniu a to testovaniu stacionarity. Bolo preukázané, že všetky tri časové rady sú stacionárne až na svojich prvých diferenciách. Tento výsledok oprávňoval pokračovat' vo výskume d’alej a po zistení časového oneskorenia bol zrealizovaný Johansenov test kointegrácie. Tento test preukázal existenciu kointegračných, teda dlhodobých vzt'ahov medzi jednotlivými veličinami. Kointegračná rovnica preukázala pozitívny vzt’ah medzi HDP a exportom Chorvátska a negatívny vplyv PZI na export. Túto skutočnost' môžeme vysvetlit' dvomi spôsobmi. Prvé vysvetlenie sa opiera o fakt, že väčšina PZI je v Chorvátsku realizovaná formou privatizácie alebo akvizície už existujúcich firiem, a tým pádom vplyv PZI na export nie je tak zretel'ný, tým by sa potvrdil aj často vytýkaný fakt $\mathrm{v}$ tejto súvislosti, že Chorvátsko v porovnaní $\mathrm{s}$ krajinami spadajúcimi do toho istého regiónu zaostáva $\mathrm{v}$ množstve PZI realizovaných na zelenej lúke a práve investície na zelenej lúke bývajú impulzom k rastu a podpore exportu. Druhé možné vysvetlenie pramení z faktu, že PZI uskutočnené na zelenej lúke sú v prvej fáze svojho fungovania, a tak konkurencieschopnost' týchto firiem na zahraničných trhoch zatial' nie je príliš vysoká. Ako posledný krok výskumu bol uskutočnený model korekcie chyby, ktorý vysvetl'uje približne 5\% mieru konvergencie $\mathrm{k}$ rovnovážnemu dlhodobému vzt’ahu v prípade vzniku krátkodobých šokov.

\section{Literatura}

BORENSZTEIN, E.J., GREGORIO, D., LEE, J.W. (1998). How does foreign direct investment affect ecnomic growth? NBER Working paper No. 3, NBER. CIPRA, T. (2008). Finanční ekonometrie. Praha: Ekopress.

CHAKRABORTY, C., BASU, P. (2002). Foreign direct investment and growth in India. Applied Economics 9: 1061-1073.

http://dx.doi.org/10.1080/00036840110074079
DICKEY, D.A., FULLER, W.A. (1979). Distributions of the estimators for Autoregressive time series with a unit root. Journal of the American Statistical Association 74: 427-431. http://dx.doi.org/10.2307/2286348

DRITSAKI, M., DRITSAKI, C., ADAMOPOULOS, A. (2004). A Causual Relationship between Trade, Foreign Direct Investment and Economic Growth for Greece. American Journal of Applied Sciences 1: 230 235. http://dx.doi.org/10.3844/ajassp.2004.230.235

FABRY, N. H. (2001). The role of inward - FDI in the transition countries of Europe. In: Enterprise in transition. Split: Faculty of Economics Split, 10321055.

FERIDUN, M., SISSOKO, Y. (2006). Impact of FDI on Economic Development: A Causality Analysis for Singapore, 1976 - 2002. In: 6th Global Conference on Business \& Economics, Cambridge: Harvard University.

JOHANSEN, S. (1988). Statistical Analysis of Cointegrating Vectors. Journal of Economic Dynamics and Control 12: 231-254. http://dx.doi.org/10.1016/0165-1889(88)90041-3

JOHANSEN, S., JUSELIUS, K. (1990). Maximum Likelihood Estimation and Inference on Cointegration, with Applications to the Demand for Money. Oxford Bulletin of Economics and Statistics 52: 169-210.

http://dx.doi.org/10.1111/j.1468-

0084.1990.mp52002003.x

MOORE, D., VAMVAKIDIS, A. (2007). Economic Growth in Croatia: Potential and Constraints. IMF Working Paper No. 07/198, IMF.

NEUHAS, M. (2005). The Impact of FDI on Economic Growth. Heidelberg: Physica-Verlag.

ORR, J. (1991). The trade balance effects of foreign direkt investment in U.S. manufacturing. Federal Reserve Bank of New York Quarterly Review 16: 6376.

PACHECO-LOPÉZ, P. (2004). Foreign Direct Investment, Exports and Imports in Mexico. Kent: University of Kent.

ZAMRAZILOVÁ, E. (2006). Přímé zahraniční investice $\mathrm{V}$ ČR: makroekonomické souvislosti. Working Paper No. 7, CES VŠEM.

\section{Další zdroje}

Foreigen direct investment statistics. Zagreb: Croatian National Bank (2009). Dostupný z WWW: http://www.hnb.hr/ statistika/estatistika.htm 
Foreign Direct investment statistics (2008). Geneva: United Nations Conference on Trade and Development. Dostupný z WWW: http://stats.unctad.org/ FDI/ReportFolders/reportFolders.aspx?sCS_referer $=\&$ sCS_Chosen Lang=en

Statistical Information about Croatia (2009). Eurostat. Dostupný z WWW: http://epp.eurostat.ec.europa.eu/ portal/page/portal/statistics/themes 